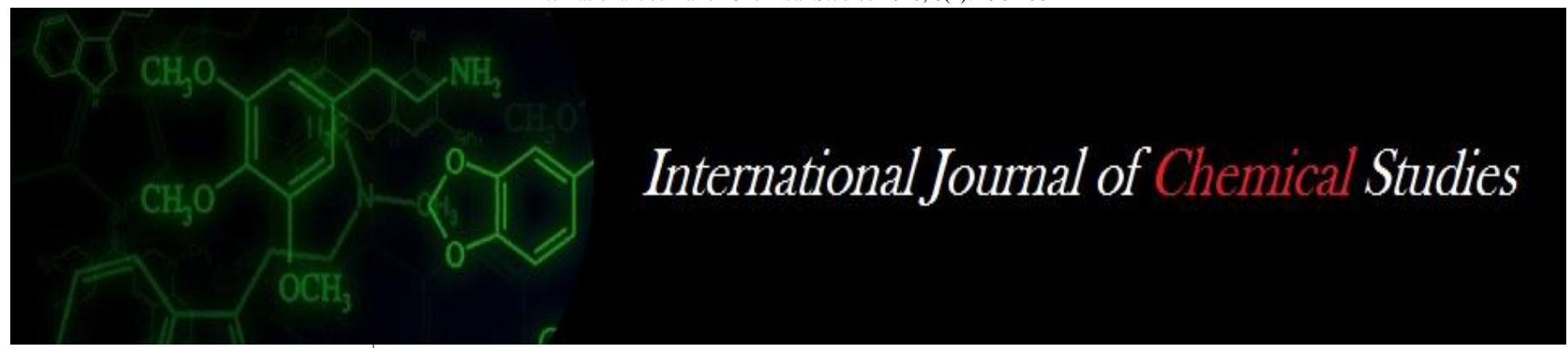

P-ISSN: 2349-8528

E-ISSN: 2321-4902

www.chemijournal.com

IJCS 2020; 8(4): 196-200

(C) 2020 IJCS

Received: 09-05-2020

Accepted: 13-06-2020

Nalish Kumar Anchal

Department of Forestry, College

of Agriculture, Indira Gandhi

Krishi Vishwavidyalaya, Raipur,

Chhattisgarh, India

Dr. Mahendra Nath Naugraiya Department of Forestry, College of Agriculture, Indira Gandhi

Krishi Vishwavidyalaya, Raipur,

Chhattisgarh, India
Corresponding Author: Nalish Kumar Anchal

Department of Forestry, College of Agriculture, Indira Gandhi

Krishi Vishwavidyalaya, Raipur,

Chhattisgarh, India

\section{Performance of rice crop in mango based Agri- horticulture system in Chhattisgarh plain}

\author{
Nalish Kumar Anchal and Dr. Mahendra Nath Naugraiya
}

DOI: https://doi.org/10.22271/chemi.2020.v8.i4c.9688

\begin{abstract}
An agri-horticulture system experiment of mango + rice crop was carried out at Pikridih village, Raipur in Chhattisgarh for two tears of observations (2017-18 \& 2018-19). Mango plantation at spacing of $28 \mathrm{x}$ $28 \mathrm{~m}$ and were intercropped with rice and wheat in 2017-18 \& 2018-19. The growth performance of oryza sativa $\mathrm{L}$. var. Saran at different treatments site located between four clumps along with a separate open field plot were studies for various growth, yield attributes, yields of rice, the plant and soil nutrient status and economics of mango based AHS. Growth parameter and yield of rice crop was found significantly maximum in open field crop than agri-horticulture system. Economics of rice-wheat cropping under mango based agri-horticulture system showed meager gains as compared to monocropping but found economically viable and technically feasible by sharing the inputs of irrigation, manure and fertilizer, weeding etc. applied to agriculture crops.

The result of this investigation showed that highest rice yield is found under open field as compared to other treatments under mango based agri-horticulture system.
\end{abstract}

Keywords: Population, No. of tiller, crop height, yield, and harvest index

\section{Introduction}

Agro-forestry the developing of trees and harvests in communicating blends, is presently perceived as a way to deal with increment ranch profitability in low info and asset circumstances. Later examinations in agro-forestry try to comprehend the working of associating segments and the systems by which relative preferred position happens through communications.

Agro-forestry service in numerous occasions tends to a fundamental issue in agro-ecology: the shortage of beneficial land for farming interests. Many, if not most, agro-forestry frameworks have created over significant stretches of time because of collaborations between agro-ecology conditions, plant assorted variety and rancher assets and necessities. As Nair (1998) notes, much starting examination in agro-forestry was enlightening or applied, and model innovations were created to address explicit creation constraints being developed "problem areas" were land quality and accessibility not overpowering restrictions, various issues, for example, crop yields, supplement accessibility, protection and environmental help capacities and fuelwood and timber creation would get disputable. The normal assets, for example, carbon and different components that are put away in environments, for example, woods and prairies are presently being removed and misused and the land that gets drained of its unique vegetation is then utilized either to attempt or produce wares for human needs, or are deserted as badlands. One goals of this proceeding with corruption is to keep up and upgrade the elements of woody perennials inside a streamlined agro-environment while improving the absolute profitability of the framework.

Chhattisgarh state is rich in forest (43.6\%) and has a vast variety of minor forest products to favorable in each agro-climatic zone. Rice is the major crop $(27.24 \%$ of geographical area of Chhattisgarh) cultivated with performance of on Acacia nilotica, Butea monosperma, Gmelina arborea, Azadirachta indica, Delbergia sissoo etc bunds of as part of traditional agroforestry system.

Agro-forestry can provide a sound ecological basis for increased crop and animal productivity, more dependable economic returns, and greater diversity in social benefits on a sustained basis (Rahim, 1997). 
Agro-forestry although not new in itself, requires new strategies and technologies as compared to traditional or modern agriculture and forestry (Dhyani et al., 2009).

\section{Materials and Methods}

The investigation site Raipur, is arranged in Chhattisgarh extended between $22^{\circ} 33^{\prime} \mathrm{N}$ to $21^{\circ} 14^{\prime} \mathrm{N}$ scope and $82^{\circ} 6^{\prime}$ to $81^{\circ} 38 ' \mathrm{E}$ longitude with a rise of $296 \mathrm{~m}$ over the mean ocean level. It is encompassed by Bilaspur in the north, Durg in the west, Baster in the south and Raigarh in the east. Topographical region of the state is $135,191 \mathrm{~km} 2$. The district is known for its crude horticulture practices and destitution as a result of the poor financial status and absence of education. The climatic condition of test site is sub-moist dry tropical. The region gets a typical yearly precipitation of $1250 \mathrm{~mm}$, of which $80 \%$ occurs during swirling season from June to end of September and discontinuous precipitation during October to February. The mean month to month most noteworthy temperature reaches out between $27.3^{\circ} \mathrm{C}$ in December and $42.3^{\circ} \mathrm{C}$ in May and least temperature varies between $13.2^{\circ} \mathrm{C}$ in December and $28.3^{\circ} \mathrm{C}$ in May. Raipur has three indisputable geological game plans viz., Bijapur, Cuddapha, Dharwar and
Archean, Lithographically, it is gathered into seven areas, to be explicit, Raipur shale and limestone, Gunderdhi shale, Khairagarh and ston, Cuddapa Chamar limestone, Chandrapur sand Stone coarseness, Dharwar rock, Granite and Gneisses. The dirt of Raipur has a place with four distinct requests viz; Entisols, Vertisols, Inceptisols and Alfisols.

Experimental site: - Vimal Gupta farm at village Pikridih, Raipur (C.G.)

1. Plantation: Mango (Dasahari) plantation was done in July 2001

2. Tree Spacing: Mango plantation was done $28 \mathrm{X} 28 \mathrm{~m}$. on bunds.

3. Crop: Tow season with Rice-Wheat rotation

3a. Irrigation: Twice in a weak, as and when required. 3b. Fertilizer (RDF)

Basal dose: $100 \mathrm{~kg} \mathrm{~N}, 60 \mathrm{~kg} \mathrm{P}_{2} \mathrm{O}_{5} \& 40 \mathrm{~kg} \mathrm{~K}_{2} \mathrm{O} / \mathrm{ha}$ in rice and wheat. Potash $60 \mathrm{~kg} / \mathrm{ha}$ and Zing Sulphate $20 \mathrm{~kg} / \mathrm{ha}, \mathrm{N}$ is applied in 3 split dozes after 60 days $40 \mathrm{Kg}$ and 120 days 40 $\mathrm{Kg}$.

Table 1: Experimental details

\begin{tabular}{|c|c|}
\hline Crops & $\begin{array}{l}\text { Rice (Oryza sativa) and Wheat (Triticum aestivum) } \\
\text { Kharif- Rice (var. Sarna) cropping period 100-120 day } \\
\text { Rabi- Wheat (var. Sarbti) cropping period 90-130 days. }\end{array}$ \\
\hline Design of Experiment & : Randomized Block Design \\
\hline Treatments & $\begin{array}{l}4 \\
\mathrm{~T}_{1} \text { Centre of four Trees } \\
\mathrm{T}_{2} \text { between East-West tree stands } \\
\mathrm{T}_{3} \text { between North-South tree stands } \\
\mathrm{T}_{4} \text { Open Field (Control) }\end{array}$ \\
\hline Year & 2 \\
\hline Replications & $: 3$ \\
\hline Design & RBD \\
\hline
\end{tabular}

Table 2: Statistical Configuration for both Rice

\begin{tabular}{|c|c|c|c|c|c|}
\hline & Replication & Treatment & Year & Error & Total \\
\hline $\mathbf{n}$ & 3 & 4 & 2 & - & 24 \\
\hline df & 2 & 3 & 1 & 17 & 23 \\
\hline
\end{tabular}

\section{Results and Discussion \\ Growth performance of rice crop \\ Plant population $\left(\mathbf{m}^{-2}\right)$}

The growth parameters of Rice viz., Plant population, plant height $(\mathrm{cm})$, numbers of tillers per plant, number of leaves, root length $(\mathrm{cm})$, shoot length $(\mathrm{cm})$, Fresh \& dry weight of leaves (gm) Fresh \& dry weight of root (gm) Fresh \& dry weight of shoot $(\mathrm{gm})$ as observed during the course of investigations were recorded and presented in table-3.

a. Effect of Treatments: Effect of treatments pertaining to various crop growing location under mango trees as well as open field on plant population of rice crop was found statistically significant variations $(P<0.05)$. The maximum average plant population was observed $62.9 \mathrm{~m}$ ${ }^{2}$ in $\mathrm{T}_{4}$ followed by $60.9,59.8$ and $56.1 \mathrm{~m}^{-2}$ in $\mathrm{T}_{1}, \mathrm{~T}_{2}$ and $\mathrm{T}_{3}$ respectively at 105 DAS. The overall percentage of plant population showed highest reduction by with 10.81 per cent, 4.93 and 3.18 percent in treatment $T_{3}, T_{2}$ and $T_{1}$ respectively as compared to open field crop condition at the time of crop maturity (Table-3).

b. Effect of Year: Effect of year on plant population showed statistically significant variations $(P<0.05)$. The maximum average plant height of rice crop was observed
$61.8 \mathrm{~m}^{-2}$ in $2^{\text {nd }}$ year and $58 \mathrm{~m}^{-2}$ in $1^{\text {st }}$ year at $105 \mathrm{DAS}$. Over all plant population of rice crop was recorded less in $1^{\text {st }}$ year as compare to $2^{\text {nd }}$ year. The average plant population of rice crop increased much faster in $2^{\text {nd }}$ year than $1^{\text {st }}$ year.

c. Effect of interaction of Treatment $x$ Year: The interaction of treatment and year was found statistically non-significant. The average plant population of rice crop at 105 DAS was recorded highest for $\mathrm{T}_{4} \times \mathrm{Y}_{2}\left(65.3 \mathrm{~m}^{-2}\right)$ followed by $62 \mathrm{~m}^{-2}$ in both of $\mathrm{T}_{1} \times \mathrm{Y}_{2}$ and $\mathrm{T}_{2} \times \mathrm{Y}_{2}$ with lowest height $54.3 \mathrm{~m}^{-2}$ for $\mathrm{T}_{3} \times \mathrm{Y}_{1}$ interaction, afterward it was remained higher in open field crop $\left(\mathrm{T}_{4}\right)$ in $2^{\text {nd }}$ year at 105 DAS.

\section{Number of tillers plant ${ }^{-1}$}

The number of tillers of rice crop was counted at after final harvesting and average number of tillers was presented in Table-3 for role of treatment, year and their interaction.

a. Effect of treatments: Effect of treatments on formation of per plant tillers in rice crop was found statistically significant $(P<0.05)$. The maximum average number of tillers was observed 11.9 plant $^{-1}$ in $\mathrm{T}_{4}$ followed by 11.1, 9.6 and 9 plant $^{-1}$ in $\mathrm{T}_{1}, \mathrm{~T}_{2}$ and $\mathrm{T}_{3}$ respectively at $105 \mathrm{DAS}$. The increase in number of tillers was followed more or less similar pattern during crop season. The population of tillers Plant ${ }^{-1}$ showed reducing trend in $\mathrm{T}_{3}, \mathrm{~T}_{2}$ and $\mathrm{T}_{1}$ with 26.83, 21.95 and 9.76 per cent respectively as compared to crop grown in open field $(12.3 \%)$ at the time of maturity (Table-3). 
b. Effect of year: Effect of year on number of tillers showed statistically significant variations $(P<0.05)$. The maximum plant ${ }^{-1}$ average number of tillers was observed 10.8 plan $^{-1}$ in $2^{\text {nd }}$ year and 10.1 plant $^{-1} 1^{\text {st }}$ year. Over all number of tiller of rice crop was recorded less in $1^{\text {st }}$ year as compared to $2^{\text {nd }}$ year. The average number of tillers of rice crop increased much faster in $2^{\text {nd }}$ year than $1^{\text {st }}$ year.

c. Effect of interaction of treatment $x$ year: The interaction of treatment and year was also found statistically non-significant at all the observation for population of tillers plant $^{-1}$ (Table-3). The average numbers of tillers at 105 DAS was recorded highest 12 plant $^{-1}$ for $\mathrm{T}_{4} \times \mathrm{Y}_{2}$ followed by 11.8 plant $^{-1}$ for $\mathrm{T}_{4} \times \mathrm{Y}_{1}$ with minimum numbers of tillers 8.3 plant $^{-1}$ for $T_{3} \times Y_{1}$.

Table 3: Growth performance of Rice crop under Mango based Traditional Agri-horticulture system

\begin{tabular}{|c|c|c|c|}
\hline Attributes & $\begin{array}{c}\text { Plant population } \\
\left(\mathbf{m}^{-2}\right)\end{array}$ & $\begin{array}{l}\text { No. of tiller } \\
\left.\text { (plant }{ }^{-1}\right)\end{array}$ & $\begin{array}{l}\text { Plant height } \\
\left(\text { cm plant }^{-1}\right)\end{array}$ \\
\hline \multicolumn{4}{|c|}{ Treatments } \\
\hline $\mathrm{T}_{1}$ & $60.9 \pm 1.9$ & $11.1 \pm 0.8$ & $98.9 \pm 10.6$ \\
\hline $\mathrm{T}_{2}$ & $59.8 \pm 3.2$ & $9.6 \pm 0.9$ & $90.9 \pm 5.4$ \\
\hline $\mathrm{T}_{3}$ & $56.1 \pm 2.6$ & $9 \pm 0.9$ & $84.9 \pm 5.1$ \\
\hline $\mathrm{T}_{4}$ & $62.9 \pm 2.8$ & $11.9 \pm 0.6$ & $105.1 \pm 7.7$ \\
\hline SEm \pm & 0.24 & 0.26 & 0.22 \\
\hline $\mathrm{SEd} \pm$ & 0.34 & 0.37 & 0.31 \\
\hline $\mathrm{CD}($ at $5 \%)$ & 0.72 & 0.77 & 0.65 \\
\hline \multicolumn{4}{|c|}{ Year } \\
\hline $\mathrm{Y}_{1}$ & $58 \pm 2.8$ & $10.1 \pm 1.6$ & $95 \pm 7.1$ \\
\hline $\mathrm{Y}_{2}$ & $61.8 \pm 3.0$ & $10.8 \pm 1.1$ & $94.9 \pm 10.9$ \\
\hline SEm \pm & 0.17 & 0.18 & 0.15 \\
\hline $\mathrm{SEd} \pm$ & 0.24 & 0.26 & 0.22 \\
\hline $\mathrm{CD}($ at $5 \%)$ & 0.51 & 0.55 & NS \\
\hline \multicolumn{4}{|c|}{ Interaction of Treatment X Year } \\
\hline $\mathrm{T}_{1} \mathrm{X} \mathrm{Y}_{1}$ & $59.8 \pm 0.5$ & $11 \pm 0.8$ & $96.3 \pm 5.5$ \\
\hline $\mathrm{T}_{2} \mathrm{X} \mathrm{Y}_{1}$ & $57.5 \pm 1.7$ & $9.3 \pm 0.5$ & $92.8 \pm 7.5$ \\
\hline $\mathrm{T}_{3} \mathrm{X} \mathrm{Y}_{1}$ & $54.3 \pm 1.5$ & $8.3 \pm 0.5$ & $87 \pm 6.7$ \\
\hline $\mathrm{T}_{4} \mathrm{X} \mathrm{Y}_{1}$ & $60.5 \pm 0.6$ & $11.8 \pm 0.5$ & $104 \pm 6.5$ \\
\hline $\mathrm{T}_{1} \mathrm{X} \mathrm{Y}_{2}$ & $62 \pm 2.2$ & $11.3 \pm 1.0$ & $101.5 \pm 14.6$ \\
\hline $\mathrm{T}_{2} \mathrm{X} \mathrm{Y}_{2}$ & $62 \pm 2.6$ & $10 \pm 1.2$ & $89 \pm 1.4$ \\
\hline $\mathrm{T}_{3} \mathrm{X} \mathrm{Y}_{2}$ & $58 \pm 2.2$ & $9.8 \pm 0.5$ & $82.8 \pm 1.7$ \\
\hline $\mathrm{T}_{4} \mathrm{X} \mathrm{Y}_{2}$ & $65.3 \pm 1.7$ & $12 \pm 0.8$ & $106.3 \pm 9.6$ \\
\hline SEm \pm & 0.34 & 0.37 & 0.31 \\
\hline SEd \pm & 0.48 & 0.52 & 0.44 \\
\hline $\mathrm{CD}$ (at $5 \%$ ) & NS & NS & NS \\
\hline
\end{tabular}

\section{Plant height (cm)}

The plant height of rice crop was measured at final harvesting and it was presented in Table-3 for treatments, year and their interaction.

a. Effect of treatments: Effect of treatments on growth in plant height was found statistically significant $(P<0.05)$ during crop growth period. The maximum plant height of rice crop was observed $105.1 \mathrm{~cm}$ in $\mathrm{T}_{4}$ followed by 98.9 , 90.9 and $84.9 \mathrm{~cm}$ in $\mathrm{T}_{1}, \mathrm{~T}_{2}$ and $\mathrm{T}_{3}$ respectively at 105 DAS. The growth pattern in plant height of rice crop was more or less similar during crop season. When the data compared with open field crop, there was maximum reduction was seen in crop height in $\mathrm{T}_{3}$ (19.22 per cent) at crop maturity i.e. $105 \mathrm{DAS}$ and it was 13.51 and 5.90 per cent in treatment $\mathrm{T}_{2}$ and $\mathrm{T}_{1}$ respectively. (Table-3).

b. Effect of year: The plant height of rice crop showed statistically non-significant $(P<0.05)$. The maximum plant height was observed 95 and $94.9 \mathrm{~cm}$ in $1^{\text {st }}$ year and $2^{\text {nd }}$ year at 105 DAS. Over all the plant height was recorded less in $2^{\text {nd }}$ year as compared to $1^{\text {st }}$ year. (Table3).

c. Effect of interaction of treatment $x$ year: The interaction of treatment and year was found statistically non-significant. The plant height of rice crop at 105 DAS was noted highest $106.3 \mathrm{~cm}$ for $\mathrm{T}_{4} \times \mathrm{Y}_{2}$ followed by 104 $\mathrm{cm}$ for $\mathrm{T}_{4} \times \mathrm{Y}_{1}$ with lowest height $82.8 \mathrm{~cm}$ for $\mathrm{T}_{3} \times \mathrm{Y}_{2}$. (Table-3).

Similarly Bisaria et al. (1995) reported lower growth and yield of wheat crop under agro-forestry system and higher result of growth in yield in sole crop as compared to agroforestry system due to less competition for available resources.

\section{Yields attributes and yield of rice crop Length of panicle}

The length of panicle $(\mathrm{cm})$ of rice crop was measured final harvesting and it was presented in Table-4 for treatments, year and their interactions.

a. Effect of treatments: The effect of treatment on length of panicle was found statistically non-significant $(P<$ $0.05)$ results during growth period. The maximum length of panicle was observed $22.9 \mathrm{~cm}$ in $\mathrm{T}_{4}$ followed by 22.8 , 22.3 and $22.1 \mathrm{~cm}$ in $\mathrm{T}_{2}, \mathrm{~T}_{1}$ and $\mathrm{T}_{3}$ respectively at 105 DAS. Where the reduction in length of panicle as compared to open field crop $\left(\mathrm{T}_{4}\right)$ was noticed 3.49 per cent in $\mathrm{T}_{3}$ followed by $2.62,0.44$ per cent in $\mathrm{T}_{1}$ and $\mathrm{T}_{2}$ respectively at the time of maturity (i.e. 105 DAS) (Table-4).

b. Effect of year: The length of panicle showed statistically significant $(P<0.05)$ results for 105 DAS observation. The maximum length of panicle was observed $23.4 \mathrm{~cm}$ in $1^{\text {st }}$ year and $21.6 \mathrm{~cm} 2^{\text {nd }}$ year at 105 DAS time of crop maturity (Table-4).

c. Effect of interaction of treatment $x$ year: The interaction of treatments and year was also found statistically non-significant $(P<0.05)$ results for the observations period. The length of panicle in rice crop at 105 DAS was recorded highest for $\mathrm{T}_{4} \times \mathrm{Y}_{1}(24.0 \mathrm{~cm})$ followed by $23.8 \mathrm{~cm}$ for $\mathrm{T}_{1} \times \mathrm{Y}_{1}$ and $\mathrm{T}_{2} \times \mathrm{Y}_{1}$ with minimum $20.9 \mathrm{~cm}$ for $\mathrm{T}_{1} \times \mathrm{Y}_{2}$ interaction. It was remained higher in $\mathrm{T}_{4}$ (open) in both $1^{\text {st }}$ and $2^{\text {nd }}$ year of crop.

\section{No. of locules}

The formation of number of locules $\left(\right.$ panicle $^{-1}$ ) of rice crop was counted at time of crop maturity (105 DAS) and it was presented in Table-4 for treatments, year and their interaction.

a. Effect of treatments: The effect of treatments on number of locules was found statistically non-significant $(P<0.05)$ results during growth period. The maximum number of locules was observed 217.4 panicle $^{-1}$ in $\mathrm{T}_{4}$ followed by $200.6,189.5$ and 183.4 panicle $^{-1}$ in $\mathrm{T}_{2}, \mathrm{~T}_{1}$ and $\mathrm{T}_{3}$ respectively. The number of locules was found less in order of $(15.64 \%)$ in $\mathrm{T}_{3}$ which was followed by in $\mathrm{T}_{1}$ $(12.83 \%)$, and $\mathrm{T}_{2}(7.73 \%)$ compared to the open plot crop $\left(\mathrm{T}_{4}\right)$. (Table-4).

b. Effect of year: The number of locules panicle ${ }^{-1}$ showed statistically significant $(P<0.05)$ results. The maximum locules were observed 223.9 panicle ${ }^{-1}$ in $1^{\text {st }}$ year and 171.5 panicle $^{-1} 2^{\text {nd }}$ years at time of crop maturity (105 DAS) (Table-4). 
c. Effect of interaction of treatment $x$ year: The interaction of treatments and year was found statistically non-significant $(P<0.05)$ during growth period. The number of locules was recorded highest in $\mathrm{T}_{4} \mathrm{X} \mathrm{Y}_{1}(251.3$ panicle $^{-1}$ ) followed by 231.3 and 221.5 panicle $^{-1}$ for $T_{1} \mathrm{X}$
$\mathrm{Y}_{1}$ and $\mathrm{T}_{2} \times \mathrm{Y}_{1}$ respectively with minimum 147.8 panicle ${ }^{1}$ for $\mathrm{T}_{1} \times \mathrm{Y}_{2}$ interaction. However it was remained higher in open field crop $\left(\mathrm{T}_{4}\right)$ for $1^{\text {st }}$ and $2^{\text {nd }}$ year at time of crop maturity.

Table 4: Yield attributes and yield of rice crop under Mango based Traditional Agri-horticulture system

\begin{tabular}{|c|c|c|c|c|c|c|}
\hline Attributes & Panicle length (cm) & $\begin{array}{c}\text { No. of Locules } \\
\left(\text { panicle }^{-1}\right)\end{array}$ & $\begin{array}{c}\text { Number of effective } \\
\text { tiller }\left(\text { plant }^{-1}\right)\end{array}$ & $\begin{array}{l}\text { Grain } \\
\left(\text { qha }^{-1}\right)\end{array}$ & $\begin{array}{l}\text { Straw } \\
\left(\mathbf{q h a}^{-1}\right)\end{array}$ & $\begin{array}{c}\text { Harvest } \\
\text { index }(\%)\end{array}$ \\
\hline \multicolumn{7}{|c|}{ Treatments } \\
\hline $\mathrm{T}_{1}$ & $22.3 \pm 2.7$ & $189.5 \pm 52.6$ & $8.8 \pm 1.0$ & $37.8 \pm 10.4$ & $50.8 \pm 26.0$ & 42.66 \\
\hline $\mathrm{T}_{2}$ & $22.8 \pm 1.6$ & $200.6 \pm 32.7$ & $8.1 \pm 1.4$ & $36.4 \pm 8.7$ & $55.6 \pm 21.0$ & 39.58 \\
\hline $\mathrm{T}_{3}$ & $22.1 \pm 1.4$ & $183.4 \pm 50.0$ & $7.0 \pm 1.3$ & $25.1 \pm 9.9$ & $45.6 \pm 18.1$ & 35.51 \\
\hline $\mathrm{T}_{4}$ & $22.9 \pm 1.6$ & $217.4 \pm 42.7$ & $8.8 \pm 1.3$ & $44.3 \pm 7.9$ & $75.9 \pm 18.2$ & 36.86 \\
\hline SEm \pm & 0.2 & 0.3 & 0.2 & 0.1 & 0.1 & \\
\hline $\mathrm{SEd} \pm$ & 0.3 & 0.4 & 0.2 & 0.2 & 0.2 & \\
\hline $\mathrm{CD}($ at $5 \%)$ & NS & NS & 0.5 & 0.4 & 0.4 & \\
\hline \multicolumn{7}{|c|}{ Year } \\
\hline $\mathrm{Y}_{1}$ & $23.4 \pm 0.8$ & $223.9 \pm 24.8$ & $7.9 \pm 0.9$ & $32.2 \pm 9.7$ & $40.6 \pm 15.3$ & 44.23 \\
\hline $\mathrm{Y}_{2}$ & $21.6 \pm 0.5$ & $171.5 \pm 16.2$ & $8.4 \pm 0.7$ & $39.7 \pm 6.5$ & $73.3 \pm 11.6$ & 35.15 \\
\hline $\mathrm{SEm} \pm$ & 0.2 & 0.2 & 0.1 & 0.1 & 0.1 & \\
\hline $\mathrm{SEd} \pm$ & 0.2 & 0.3 & 0.2 & 0.1 & 0.1 & \\
\hline $\mathrm{CD}($ at $5 \%)$ & 0.5 & 0.6 & $\mathrm{NS}$ & NS & 0.3 & \\
\hline \multicolumn{7}{|c|}{ Interaction of Treatment X Year } \\
\hline $\mathrm{T}_{1} \mathrm{X} \mathrm{Y}_{1}$ & $23.8 \pm 2.5$ & $231.3 \pm 26.3$ & $8.5 \pm 1.3$ & $35.0 \pm 12.9$ & $30.0 \pm 16.3$ & 53.85 \\
\hline $\mathrm{T}_{2} \mathrm{X} \mathrm{Y}_{1}$ & $23.8 \pm 1.3$ & $221.5 \pm 11.1$ & $8.0 \pm 1.6$ & $32.1 \pm 7.7$ & $40.0 \pm 14.1$ & 44.54 \\
\hline $\mathrm{T}_{3} \mathrm{X} \mathrm{Y}_{1}$ & $22.3 \pm 1.0$ & $191.8 \pm 69.4$ & $6.5 \pm 1.3$ & $19.3 \pm 6.2$ & $30.0 \pm 8.2$ & 39.09 \\
\hline $\mathrm{T}_{4} \mathrm{X} \mathrm{Y}_{1}$ & $24.0 \pm 0.8$ & $251.3 \pm 23.8$ & $8.5 \pm 1.7$ & $42.5 \pm 9.6$ & $62.5 \pm 15.0$ & 40.48 \\
\hline $\mathrm{T}_{1} \mathrm{X} \mathrm{Y}_{2}$ & $20.9 \pm 2.3$ & $147.8 \pm 33.4$ & $9.0 \pm 0.8$ & $40.5 \pm 8.2$ & $71.5 \pm 12.6$ & 36.16 \\
\hline $\mathrm{T}_{2} \mathrm{X} \mathrm{Y}_{2}$ & $21.9 \pm 1.3$ & $179.8 \pm 34.9$ & $8.3 \pm 1.3$ & $40.8 \pm 8.3$ & $71.3 \pm 13.5$ & 36.38 \\
\hline $\mathrm{T}_{3} \mathrm{X} \mathrm{Y}_{2}$ & $22.0 \pm 1.8$ & $175.0 \pm 28.6$ & $7.5 \pm 1.3$ & $31.0 \pm 9.9$ & $61.3 \pm 6.7$ & 33.60 \\
\hline $\mathrm{T}_{4} \mathrm{X} \mathrm{Y}_{2}$ & $21.8 \pm 1.3$ & $183.5 \pm 24.9$ & $9.0 \pm 0.8$ & $46.7 \pm 5.8$ & $89.3 \pm 8.3$ & 34.33 \\
\hline SEm \pm & 0.3 & 0.4 & 0.2 & 0.2 & 0.2 & \\
\hline SEd \pm & 0.5 & 0.6 & 0.4 & 0.2 & 0.3 & \\
\hline $\mathrm{CD}($ at $5 \%)$ & NS & NS & NS & NS & NS & \\
\hline
\end{tabular}

\section{No. of effective tiller plant $^{-1}$ )}

The number of effective tiller plant $^{-1}$ in rice crop was counted at crop maturity period and it was presented in Table-4 for treatments, year and their interactions.

a. Effect of treatments: The effect of treatment on strength of effective tiller was found statistically significant $(P<0.05)$ during growth period. The maximum effective tiller was observed 8.8 plant $^{-1}$ in both $\mathrm{T}_{1}$ and $\mathrm{T}_{4}$ followed by 8.1 and 7.0 plant $^{-1}$ in $\mathrm{T}_{2}$ and $\mathrm{T}_{3}$ respectively at 105 DAS. Where populations of effective tiller showed reduction by 20.45 per cent in $T_{3}$ and 7.95 per cent in $T_{2}$ respectively from highest value i.e. 8.8 tillers plant ${ }^{-1}$. (Table-4).

b. Effect of year: The strength of effective tiller showed statistically non-significant $(P<0.05)$ results for both the observation. The effective tiller was observed 8.4 plant $^{-1}$ in $2^{\text {nd }}$ year and 7.9 plant $^{-1} 1^{\text {st }}$ year at 105 DAS (Table-4).

c. Effect of interaction of treatment $x$ year: The interaction of treatments and year was found statistically non-significant $(P<0.05)$ observations during growth period. The population of effective tillers at $105 \mathrm{DAS}$ was recorded highest 9.0 plant $^{-1}$ for both $\mathrm{T}_{4} \times \mathrm{Y}_{2}$ and $\mathrm{T}_{1} \mathrm{X}$ $\mathrm{Y}_{2}$ followed by 8.5 plant $^{-1}$ for $\mathrm{T}_{1} \times \mathrm{Y}_{1}$ with minimum 6.5 plant $^{-1}$ for $\mathrm{T}_{3} \times \mathrm{Y}_{1}$ interaction (Table-4).

\section{Grain yield}

The grain yield $\left(\mathrm{qha}^{-1}\right)$ of rice crop was recorded at time of crop maturity and it was presented in Table- 4 for treatments, year and their interaction. a. Effect of treatments: The effect of treatments on grain yield was found statistically significant results $(P<0.05)$. The maximum grain yield was observed $44.3 \mathrm{qha}^{-1}$ in $\mathrm{T}_{4}$ followed by $37.8,36.4$ and $25.1 \mathrm{qha}^{-1}$ in $\mathrm{T}_{1}, \mathrm{~T}_{2}$ and $\mathrm{T}_{3}$ respectively. The grain yield was found less in order of $\mathrm{T}_{3}(43.34 \%)$ which was followed by $\mathrm{T}_{2}(17.83 \%)$ and $\mathrm{T}_{1}$ $(14.67 \%)$ as compared to the open plot crop $\left(\mathrm{T}_{4}\right)$. (Table4).

b. Effect of year: The grain yield $\left(\mathrm{qha}^{-1}\right)$ showed statistically non-significant $(P<0.05)$, with maximum grain yield was observed $39.7 \mathrm{qha}^{-1}$ in $2^{\text {nd }}$ year and 32.2 $\mathrm{qha}^{-1}$ in $1^{\text {st }}$ year and it was $18.9 \%$ less in $1^{\text {st }}$ year crop (Table-4).

c. Effect of interaction of treatment $x$ year: The interaction of treatments and year was found statistically non-significant $(P<0.05)$ for all the observation. The grain yield was recorded highest in $\mathrm{T}_{4} \times \mathrm{Y}_{2}\left(46.7 \mathrm{qha}^{-1}\right)$ followed by 42.5 and $40.8 \mathrm{qha}^{-1}$ for $\mathrm{T}_{4} \times \mathrm{Y}_{1}$ and $\mathrm{T}_{2} \times \mathrm{Y}_{2}$ with minimum of $19.3 \mathrm{qha}^{-1}$ for $\mathrm{T}_{3} \times \mathrm{Y}_{1}$ interaction respectively. However it was remained higher in open field crop $\left(\mathrm{T}_{4}\right)$ for $1^{\text {st }}$ and $2^{\text {nd }}$ year at time of crop maturity.

\section{Straw yield}

The straw yield $\left(\mathrm{qha}^{-1}\right)$ of rice crop was recorded at time of crop maturity and it was presented in Table- 4 for treatments, year and their interaction.

a. Effect of treatments: The effect of treatments on straw yield was found statistically significant results $(P<0.05)$. The maximum straw yield was observed $75.9 \mathrm{qha}^{-1}$ in $\mathrm{T}_{4}$ 
followed by 55.6, 50.8 and $45.6 \mathrm{qha}^{-1}$ in $\mathrm{T}_{2}, \mathrm{~T}_{1}$ and $\mathrm{T}_{3}$ respectively. The straw yield was found less in order of $\mathrm{T}_{3}(39.92 \%)$ which was followed by $\mathrm{T}_{1}(33.07 \%)$ and $\mathrm{T}_{2}$ $(26.75 \%)$ as compared to the open plot crop $\left(\mathrm{T}_{4}\right)$. (Table4).

b. Effect of year: The straw yield $\left(\mathrm{qha}^{-1}\right)$ showed statistically significant results $(P<0.05)$, with maximum of $73.3 \mathrm{qha}^{-1}$ in $2^{\text {nd }}$ year and $40.6 \mathrm{qha}^{-1}$ in $1^{\text {st }}$ year and it was $44.6 \%$ less in $1^{\text {st }}$ year crop (Table-4).

c. Effect of interaction of treatment $x$ year: The interaction of treatments and year was found statistically non-significant $(P<0.05)$. The straw yield was recorded highest in $\mathrm{T}_{4} \times \mathrm{Y}_{2}\left(89.3 \mathrm{qha}^{-1}\right)$ followed by 71.5 and 71.3 $\mathrm{qha}^{-1}$ for $\mathrm{T}_{1} \times \mathrm{Y}_{2}$ and $\mathrm{T}_{2} \times \mathrm{Y}_{2}$ with minimum of $30.0 \mathrm{qha}^{-1}$ in both $\mathrm{T}_{1} \times \mathrm{Y}_{1}$ and $\mathrm{T}_{3} \times \mathrm{Y}_{1}$ interaction respectively. However it was remained higher in $\left(\mathrm{T}_{4}\right)$ open field crop for $2^{\text {nd }}$ year at time of crop maturity.

\section{Harvest index (\%)}

The harvest index (\%) of rice crop was recorded at time of crop maturity and it was presented in Table- 4 for treatments, year and their interaction.

a. Effect of treatments: The effect of treatments on harvest index was found statistically significant results $(P<0.05)$. The maximum harvest index was observed $42.66 \%$ in $\mathrm{T}_{1}$ followed by $39.58 \%, 36.86 \%$ and $35.51 \%$ in $\mathrm{T}_{2}, \mathrm{~T}_{4}$ and $\mathrm{T}_{3}$ respectively. The increase in harvest index of rice crop was more or less same during crop season. (Table-4).

b. Effect of year: The harvest index (\%) showed statistically significant $(P<0.05)$, with maximum harvest index was observed $(44.23 \%)$ in $1^{\text {st }}$ year and $(35.15 \%)$ in $2^{\text {nd }}$ year and it was $20.5 \%$ less in $2^{\text {nd }}$ year crop (Table- 4$)$.

c. Effect of interaction of treatment $x$ year: The interaction of treatments and year was found statistically significant $(P<0.05)$. The average harvest index was recorded highest for $\mathrm{T}_{1} \times \mathrm{Y}_{1}(53.85 \%)$ followed by $44.54 \%$ and $40.48 \%$ for $\mathrm{T}_{2} \times \mathrm{Y}_{1}$ and $\mathrm{T}_{4} \times \mathrm{Y}_{1}$ with minimum of $33.60 \%$ for $\mathrm{T}_{3} \times \mathrm{Y}_{2}$ interaction at time of crop maturity.

The yield result of the present study has also been supported by the finding of many earlier workers (Dhillon et al., 1997 and Sharma et al., 1994) $[9,10]$, they also observed that agricultural crop yield was increased with increasing the crop distance from the tree base under AFS.

Similarly, Khan and Ehrenriech (1994) ${ }^{[11]}$ studied on effect of increasing the crop distance from Acacia nilotica trees the growth of wheat crop was lowest near the trees and increased with for distance from tree. The test weight of grain was found minimum in crop at $1 \mathrm{~m}$ distance and it gradually increased up to $11 \mathrm{~m}$., similarly the grain yield was lowest near the trees and gradually increased with for distance from the trees.

\section{Acknowledgment}

The authors express their deep sense of gratitude to DRS, IGKV, Raipur (CG), Dean, college of Agriculture, Raipur and my supervisor. I extend my gratitude to farmer vimal gupta without their support we could not be able to commence the work smoothly.

\section{References}

1. Akber G, Ahmed M, Babar KN. Effect of tree on the yield of wheat crop. Agroforestry systems. 1990; 11:1-10
2. Baghel BS, Tiwari R, Gupta N. Productivity and profitability of mango (Mangifera indica L.) based intercropping system under rainfed agro-climatic conditions of Madhya Pradesh. South Indian Horticulture. 2004; 52(1-6):1-4.

3. Dhyani SK, Handa AK. India needs agroforestry policy urgently: issues and challanges. Indian Journal of Agroforestry. 2013; 15:1-9.

4. Bijalwan Arvind, Sharma CM, Sah VK, Raj AJ. Structure and Composition of tree and their effect on crop yield in existing agri-horti-silviculturarl and agri-hotricultural system of Garhwal Himalaya. Indian Journal Agroforestry. 2009; 11(2):26-23.

5. Ralhan PK, Singh A, Dhanda RS. Studied on the performance of wheat as intercrop under poplar (Populous deltoids Bartr. Ex Marsh) Plantation in Punjab (India). Agroforestry systems. 1992; 19:217-222.

6. Roy Zaman MR, Rahman MM. Planting Distance Effects on Mango-sweet Gourd Agroforestry System in the Mymensingh District of Bangladesh. Article no. ARJA. 28907 American research journal of Agriculture. 2016; 2(1):1-7.

7. Sarangi TK. Non Timber forest product and rural livelihood with special reference to the policies \& market in Orissa (Ed: chauhan et.al) comp odium of $1^{\text {st }}$ Indian forest congress. 2011; 2:231-236.

8. Naugaraiya MN, Puri S. Bamboo: producation and utilization. IGKV publication, 1996, 89.

9. Dhillon KS, Dhillon SK. Distribution of seleniferous soils in north-west India and associated toxicity problems in the soil- plant-animal-human continuum. Land Contamination and Reclamation. 1997; 5:313-322.

10. Sharma R, E Sharma, AN Purohit. Dry matter production and nutrient cycling in agroforestry systems of cardamom grown under the Alnus and natural forest. Agroforestry Systems. 1994; 27:293-306.

11. Khan GS, Ehrenreich JH. Effect of increasing distance from Acacia nilotica trees on wheat yield, Agro-forestry system. 1994; 25:23-29. 